\title{
Risk of surgical site infection in patients undergoing orthopedic surgery
}

\author{
Flávia Falci Ercole ${ }^{1}$ \\ Lúcia Maciel Castro Franco ${ }^{2}$ \\ Tamara Gonçalves Rezende Macieira ${ }^{3}$ \\ Luísa Cristina Crespo Wenceslau ${ }^{3}$ \\ Helena Isabel Nascimento de Resende ${ }^{3}$ \\ Tânia Couto Machado Chianca ${ }^{4}$
}

\begin{abstract}
This study aimed to identify risk factors associated with surgical site infections in orthopedic surgical patients at a public hospital in Minas Gerais, Brazil, between 2005 and 2007. A historical cohort of 3,543 patients submitted to orthopedic surgical procedures. A descriptive analysis was conducted and surgical site infection incidence rates were estimated. To verify the association between infection and risk factors, the Chi-square Test was used. The strength of association of the event with the independent variables was estimated using Relative Risk, with a $95 \%$ confidence interval and $p<0.05$. The incidence of surgical site infection was $1.8 \%$. Potential surgical wound contamination, clinical conditions, time and type of surgical procedure were statistically associated with infection. Identifying the association between surgical site infection and these risk factors is important and contributes to nurses' clinical practice.
\end{abstract}

Descriptors: Surgical Wound Infection; Risk Factors; Nursing; Orthopedics.

\footnotetext{
${ }^{1}$ RN, Ph.D. in Sciences, Adjunct Professor, Escola de Enfermagem, Universidade Federal de Minas Gerais, Belo Horizonte, MG, Brazil. E-mail: flavia.ercole@gmail.com.

${ }^{2}$ RN, Master's Student in Nursing, Escola de Enfermagem, Universidade Federal de Minas Gerais, Belo Horizonte, MG, Brazil. Hospital Governador Israel Pinheiro, Instituto de Previdência dos Servidores de Minas Gerais, Belo Horizonte, MG, Brazil. E-mail: luciamcf@terra.com.br.

3 Undergraduate students in Nursing, Escola de Enfermagem, Universidade Federal de Minas Gerais, Belo Horizonte, MG, Brazil. E-mail: Tamara - tata-macieira@hotmail.com, Luísa - luisawenceslau@gmail.com, Helena - helenainr@gmail.com.

${ }^{4}$ RN, Ph.D. in Nursing, Associate Professor, Escola de Enfermagem, Universidade Federal de Minas Gerais, Belo Horizonte, MG, Brazil. E-mail: taniachianca@gmail.com.
}

Corresponding Author:

Flávia Falci Ercole

Universidade Federal de Minas Gerais. Escola de Enfermagem

Av. Prof. Alfredo Balena, 190, Sala 220

Bairro: Santa Efigênia

CEP: 30130-100, Belo Horizonte, MG, Brasil

E-mail: flavia.ercole@gmail.com 


\section{Risco para infecção de sítio cirúrgico em pacientes submetidos a cirurgias ortopédicas}

Objetivou-se, neste estudo, identificar fatores de risco associados às infecções de sítio cirúrgico, em pacientes cirúrgicos ortopédicos, de um hospital público de Minas Gerais, Brasil, entre 2005 e 2007. Como método usou-se coorte histórica em 3.543 pacientes submetidos a cirurgias ortopédicas. Análise descritiva e taxa de incidência de infecção foram estimadas. Para verificar a associação entre a infecção e os fatores de risco usouse o teste qui-quadrado. A força da associação do evento com as variáveis independentes foi estimada pelo risco relativo, intervalo de confiança de $95 \%$ e $p<0,05$. A incidência de infecção de sítio cirúrgico foi de 1,8\%. Potencial de contaminação da ferida cirúrgica, condições clínicas do paciente, tempo cirúrgico e tipo de procedimento ortopédico foram estatisticamente associados à infecção. A identificação de associação de infecção de sítio cirúrgico aos fatores de risco mencionados é importante e contribui para a prática clínica do enfermeiro.

Descritores: Infecção da Ferida Operatória; Fatores de Risco; Enfermagem; Ortopedia.

\section{Riesgo para infección de sitio quirúrgico en pacientes sometidos a cirugías ortopédicas}

Estudio para identificar factores de riesgo asociados a infecciones de sitio quirúrgico en pacientes quirúrgicos ortopédicos de un hospital público de Minas Gerais, Brasil, entre 2005 y 2007. Cohorte histórica de 3.543 pacientes sometidos a cirugías ortopédicas. Un análisis descriptivo fue realizado y la tasa de incidencia de infección fue estimada. Para verificar la asociación entre la infección y los factores de riesgo se usó el test chicuadrado. La fuerza de la asociación del evento con las variables independientes fue estimada por el Riesgo Relativo, con un intervalo de confianza de $95 \%$ y $p<0,05$. La incidencia de infección de sitio quirúrgico fue $1,8 \%$. Fueron estadísticamente asociados a la infección el potencial de contaminación de la herida quirúrgica, las condiciones clínicas del paciente, el tiempo quirúrgico y el tipo de procedimiento ortopédico. La identificación de asociación de infección de sitio quirúrgico con los factores de riesgo mencionados es importante y contribuye para la práctica clínica del enfermero.

Descriptores: Infección de Herida Operatoria; Factores de Riesgo; Enfermería; Ortopedia.

\section{Introduction}

Healthcare-associated infections (HAI) are considered severe complications and represent a serious threat to hospitalized patients' safety ${ }^{(1-2)}$. They increase morbidity-mortality rates, hospitalization costs due to the extended hospital stay and spending on diagnostic and therapeutic procedures, besides neglecting patient's distancing from their work and family ${ }^{(3-4)}$.

Among the main HAI sites, surgical site infection (SSI) can derive from a surgical act. It is defined as any infection involving tissue, the incised organ and the cavity manipulated during a surgical procedure(5). Among SSIs, those related to orthopedic procedures are considered severe. During these surgeries, in general, implantation materials are used, which increases the risk of infection, a complication that can bring about the loss of the operated limb and even death(3,6). In Brazil, SSI ranks third among all healthcare infections and is responsible for $14 \%$ to $16 \%$ of infections in hospitalized patients, with an $11 \%$ incidence rate ${ }^{(7)}$. Some Brazilian studies evidenced orthopedic SSI rates ranging between 1.4 and $40.3 \%{ }^{(8-9)}$.

Extrinsic and intrinsic risk factors associated with orthopedic infection include the patient's clinical conditions, prolonged preoperative hospitalization time, 
surgery length, skin preparation, surgeon and team's hand degerming technique, environmental conditions of operating room, number of people inside the room, surgeon's technique and skills, use of implants, among others ${ }^{(8-12)}$

To control surgical infections and establish prevention measures, infection risk factors need to be identified, which are normally related with the host, microorganism, environment and type of implanted material. Knowing these factors is important for nursing action planning and practice, such as environmental control, bathing, perioperative infection control, medication control and incision site care ${ }^{(2,8,11,13)}$.

More solid evidence-based research is required to identify risk factors related to surgical site infection, as these can directly influence nursing practice, considering that a surgical wound increased infection risks due to the ruptured skin barrier, handling of organs and spaces and presence of implantable devices. Preventing the problem based on the monitoring of risk factors and putting in practice actions to minimize SSI should be taken into account.

In view of the above, and considering that nurses identify most situations representing SSI risks, this study is justified by its repercussion for nurses' clinical practice and its possible contribution to the future proposal of a new nursing diagnosis to NANDA International(14), appropriate for those situations that demand its prevention, specifically among surgical patients.

\section{Aims}

General: To identify the risk factors associated with SSI in orthopedic surgical patients at a large general public hospital in Belo Horizonte, Minas Gerais, Brazil, between 2005 and 2007, based on the determination of infection rates.

Specific: To estimate the global incidence level of SSI for the study period; to identify, among the variables the Hospital Control Service regularly collects, those variables that represent risk factors for SSI in orthopedic patients.

\section{Methods}

This is a historical cohort of 3,543 patients submitted to orthopedic surgical procedures, registered in a HRI database of a large general public hospital in Belo Horizonte, Minas Gerais, Brazil, between January/2005 and December/2007. The surgical patients included in the study complied with the criteria established in the
Centers for Disease Control and Prevention's (CDCAtlanta) National Nosocomial Infections Surveillance System-NNISS, as patients whose admission and discharge happen on different calendar days, with a sole operating room entry and where the surgeon made at least one skin or mucous membrane incision, including laparoscopic methods, besides closing the incision before the patient leaves the operating room ${ }^{(5)}$.

Surgical site infection was analyzed in orthopedic surgical procedures, as well as their possible risk factors. SSI categorization was based on the absence and presence of infection, and can be superficial incisional, deep incisional and organ space(5). Risk factors for SSI were considered as independent variables, i.e. those variables whose presence is associated with a greater probability than an infection will develop ${ }^{(5,11)}$ : gender; NNIS Surgical Infection Risk Index (scores 0, 1,2 and 3); surgical wound contamination potential (clean, potentially contaminated, contaminated and infected); general anesthesia (no and yes); patients' preoperative clinical conditions, analyzed using ASA I,II,III,IV and V, the criterion proposed by the American Society of Anesthesiologists ${ }^{(5,13,15)}$; emergency (no and yes); orthopedic implant (no and yes); type of surgical procedure (AMP=amputation; $F U S=$ fusion and arthrodesis; $F X=o p e n$ fracture reduction; OMS=other musculoskeletal system procedures; ONS=other nervous system procedures; PROS-Q=hip prosthesis; Other prosthesis like elbow and shoulder); surgery length ( $<120$ and $>120 \mathrm{~min}$ ) and preoperative hospitalization time ( $<04$ days and $>04$ days $)^{(11,13)}$.

To describe and characterize the orthopedic surgery patients, descriptive analysis with simple frequency distribution, central trend measures (mean and median) and variability measures like standard deviation (SD) and quartiles were used. A global SSI incidence level was estimated. Univariate analysis was applied to check the association between SSI and risk factors, using Mantel-Haenszel's $\left(\chi^{2}\right)$ Chi-square with Yates' correction, Fisher's exact test and the Chi-square test for Trend. The strength of the event's association with the independent variables was estimated through the Relative Risk (RR), with a $95 \%$ confidence interval and $p<0.05^{(16)}$.

It should be highlighted that, at the study hospital, no monitoring for SSI takes place after hospital discharge.

Approval for the study was obtained from the institution and the Institutional Review Board of the Instituto de Previdência dos Servidores do Estado de Minas Gerais (IPSEMG), protocol 384/2010. 


\section{Results}

\section{Characterization of study subjects' socio- demographic and clinical variables}

Among the 3,543 patients submitted to orthopedic surgical procedures, the mean age, preoperative hospitalization time and surgery length corresponded to 54 years $(S D=19.8)$, three days $(S D=9)$ and 80.5 minutes $(S D=41.9)$, respectively. The mean time interval between the surgery data and infection event was 95.8 days $(\mathrm{SD}=115)$.

The orthopedic surgical procedures involved $57.7 \%$ of female patients. Among all procedures performed, in $28.6 \%$, general anesthesia was used. Emergency surgeries were responsible for $0.4 \%$ of cases, and implants were placed in $41 \%$ of procedures. The orthopedic surgeries were ranked as clean wounds in $91 \%$, with a 4.6 times smaller risk of infection development when compared with other classifications. It was observed that $52.7 \%$ of patients were classified as ASA II, with a moderate systematic disease. Most patients (79\%) were classified under score zero (absence of risk factor for infection) of the NNIS Surgical Infection Risk Index, followed by score one (18.8\%).

\section{Incidence of surgical site infection}

In the group of 3,543 patients submitted to orthopedic surgical procedures, 63 surgical site infections were detected, 41 (65\%) of which occurred between the $1^{\text {st }}$ and $69^{\text {th }}$ postoperative day and 22 (35\%) after 90 days. Out of 63 SSI, 31 (49\%) were diagnosed until the $21^{\text {st }}$ day after the surgery. Thus, the global infection incidence level corresponded to $1.8 \%$ for the study period. The most frequent infections were deep surgical site infections (43\%) and osteomyelitis $(33 \%)$, totaling $76 \%$ of infections. Among all notified SSIs, $55.6 \%$ involved surgical procedures with orthopedic implants.

\section{Risk factors for SSI in orthopedic patients}

Some patient and surgical act characteristics can influence the risk of developing $\mathrm{SSI}^{(2,8-11)}$. In this study, a statistically significant association was found between the SSI and some variables (Table 1 ): surgery length $(p=0.01)$; the contamination potential of the surgical wound with $p=0.03$ (3.6\% of SSIs involved surgeries classified as potentially contaminated, contaminated and infected); the patient's clinical condition - ASA, with $<0.00$ (SSI risk tended to increase with the patient's clinical severity); the emergency nature of the surgery $(p=0.03)$ and the presence of orthopedic implants $(p=0.02)$. No statistically significant difference was found between the SSI and gender $(p=0.07)$; NNIS risk index $(p=0.18)$; age $(p=0.1)$; preoperative hospitalization time $(\mathrm{p}=0.3)$ and general anesthesia use $(R R=1.00 ; 95 \% C I=1.01-1.03 ; p=0.00)$.

Table 1 - Univariate analysis of surgical site infection and independent variables - Belo Horizonte, MG, Brazil, $2005-2007$

\begin{tabular}{|c|c|c|c|c|c|c|}
\hline \multirow{3}{*}{ Variable } & \multicolumn{4}{|c|}{ SSI } & \multirow{3}{*}{$\mathrm{RR}[95 \% \mathrm{Cl}]$} & \multirow{3}{*}{ p-value } \\
\hline & \multicolumn{2}{|c|}{ Yes $(n=63)$} & \multicolumn{2}{|c|}{ No $(n=3480)$} & & \\
\hline & $\mathbf{n}$ & $\%$ & $\mathbf{n}$ & $\%$ & & \\
\hline \multicolumn{7}{|l|}{ Gender } \\
\hline Female & 29 & 46.0 & 2017 & 57.9 & $1.0[1.0-1.02]$ & $p=0.07$ \\
\hline Male & 34 & 53.9 & 1463 & 42.0 & & \\
\hline \multicolumn{7}{|l|}{ Surgical Site Infection Risk Index* } \\
\hline Score 0 & 39 & 70.9 & 2710 & 79.1 & $0.60[0.36-1.15]$ & $p=0.18$ \\
\hline Grouped score (1, 2 and 3$)$ & 16 & 29.0 & 713 & 20.8 & & \\
\hline \multicolumn{7}{|c|}{ Surgical wound contamination potential } \\
\hline Clean & 52 & 82.5 & 3174 & 91.2 & $0.46[0.24-0.88]$ & $p=0.03$ \\
\hline Others $(\mathrm{PC}, \mathrm{C}, \mathrm{I})^{\dagger}$ & 11 & 17.5 & 306 & 8.7 & & \\
\hline \multicolumn{7}{|l|}{ General anesthesia } \\
\hline No & 33 & 52.3 & 2495 & 71.6 & $1.00[1.01-1.03]$ & $p=0.00$ \\
\hline Yes & 30 & 47.6 & 985 & 28.3 & & \\
\hline \multicolumn{7}{|l|}{ Patient's clinical conditions (ASA) } \\
\hline ASAI & 11 & 17.5 & 1293 & 37.1 & $0.36[0.19-0.69]$ & $p=0.00$ \\
\hline Grouped ASA (II, III , IV and V) & 52 & 82.5 & 2187 & 62.8 & & \\
\hline \multicolumn{7}{|l|}{ Emergency } \\
\hline No & 61 & 96.8 & 3467 & 99.6 & $1.13[0.93-1.38]$ & $p=0.03$ \\
\hline Yes & 2 & 3.2 & 13 & 0.4 & & \\
\hline
\end{tabular}


Table 1 - (continuation)

\begin{tabular}{|c|c|c|c|c|c|c|}
\hline \multirow{3}{*}{ Variable } & \multicolumn{4}{|c|}{ ssı } & \multirow{3}{*}{$\mathrm{RR}[95 \% \mathrm{Cl}]$} & \multirow{3}{*}{ p-value } \\
\hline & \multicolumn{2}{|c|}{ Yes $(n=63)$} & \multicolumn{2}{|c|}{ No $(n=3480)$} & & \\
\hline & $\mathrm{n}$ & $\%$ & $\mathrm{n}$ & $\%$ & & \\
\hline \multicolumn{7}{|l|}{ Orthopedic implant } \\
\hline No & 28 & 44 & 2092 & 60.1 & $1.01[1.0-1.02]$ & $p=0.02$ \\
\hline Yes & 35 & 56 & 1416 & 40.6 & & \\
\hline \multicolumn{7}{|l|}{ Surgical procedure type } \\
\hline AMP & 2 & 3.2 & 23 & 0.6 & $4.61[1.19-17.8]$ & $p=0.07$ \\
\hline FUS & 3 & 4.7 & 81 & 2.3 & $2.06[0.66-6.43]$ & $p=0.19$ \\
\hline $\mathrm{FX}$ & 9 & 14.3 & 662 & 19.0 & $0.71[0.35-1.44]$ & $p=0.43$ \\
\hline OMS & 29 & 46 & 2072 & 59.5 & $0.58[0.36-0.95]$ & $p=0.04$ \\
\hline ONS & 3 & 4.7 & 156 & 4.5 & $1.06[0.34-3.36]$ & $p=0.54$ \\
\hline PROS-Q & 14 & 22.2 & 289 & 8.3 & $3.06[1.71-5.47]$ & $p=0.00$ \\
\hline Other prostheses (elbow and shoulder) & 3 & 4.7 & 197 & 5.7 & $0.84[0.26-2.64]$ & $p=0.52$ \\
\hline \multicolumn{7}{|l|}{ Surgery length $(\mathrm{min})$} \\
\hline$<120$ & 50 & 79.4 & 3069 & 88.2 & $0.52[0.29-0.95]$ & $p=0.01$ \\
\hline$>120$ & 13 & 20.6 & 411 & 11.8 & & \\
\hline \multicolumn{7}{|l|}{ Preoperative hospitalization time (days) } \\
\hline$<04$ days & 47 & 74.6 & 1755 & 50.4 & $0.71[0.41-1.25]$ & $p=0.30$ \\
\hline$>04$ days & 16 & 25.4 & 725 & 20.8 & & \\
\hline
\end{tabular}

$*_{n}=55 / 3423$

† potentially contaminated, contaminated, infected

\section{Discussion}

In this study, the incidence rate of orthopedic SSI was low $(1.8 \%)$. This infection rate is inferior to the parameters found in some studies about orthopedic SSI, ranging from 5.7 to $22.7 \%^{(6,10,12)}$. A study involving orthopedic surgery patient information registered in a database found a rate under $1.5 \%$, suggesting data under-notification ${ }^{(8)}$.

The most frequent infections were deep surgical site infection (46\%) and osteomyelitis (33\%), totaling $79 \%$. Superficial incisional infections contributed were responsible for $21 \%$. Studies describe that superficial incisional infection is the most common surgical site infection ${ }^{(4,12,17-18)}$. In this study, deep infections were more frequent.

It should be highlighted that infection notifications were based on an intra-hospital search. At the study hospital, no control of patients discharged after surgery exists yet. The fact is that patients with severe infections tend to be readmitted for a new treatment. The large majority of superficial infections are normally treated in the outpatient context and the surgeon does not notify them. Thus, the epidemiological surveillance service at the institution does not consider them in its calculations, which can entail under-notification of this event.

Fifty-one percent (32) of the infections were notified after the $21^{\text {st }}$ postoperative day. This may be explained by the fact that, in more than $40 \%$ of the procedures performed, prostheses were implanted, when infections can appear in a late phase, after the patient's discharge from hospital. Although the CDC recommends surgical patient monitoring for up to 30 days ${ }^{(5,13)}$, some authors describe in their research that most surgical site infections appear within 21 postoperative days, but can take up to one year in case of implants ${ }^{(17-18)}$.

The mean age of the orthopedic surgery patients was 54 years. Other studies involved younger populations, with mean ages of 33 to 35 years ${ }^{(8-9)}$. The patient's mean length of preoperative stay was three days and the maximum 361 days. The preoperative length of stay did not reveal any association with the SSI. According to some authors, the preoperative stay is frequently associated with increased SSI ${ }^{(12-13)}$. Minimizing the hospitalization period before the surgery seems to be an important prevention measure, as long hospitalization periods enhance skin colonization by hospital microbiota(13). Patients who are ill and suffer from comorbidities should be previously treated, before the surgical procedure ${ }^{(3,11,13)}$.

Surgery length is directly connected with SSI events. Surgery length of more than 120 minutes is a risk factor for infection ${ }^{(6,19-20)}$. Longer surgery length means increased tissue exposure time and team fatigue, enhancing technical errors and decreasing the organism's systemic defenses ${ }^{(13)}$. 
In this study, patients classified as ASA II were predominant. A study involving SSI in patients submitted to hip surgery also found the same patient percentage classified as ASA II ${ }^{(12)}$. Patients with systemic diseases show a higher incidence rate of SSI, showing a direct relation between clinical severity and infection events ${ }^{(4,9-10,12)}$. It can be inferred that healthy patients are at lesser risk of evolving to an SSI in comparison with patients suffering from some kind of disease ${ }^{(12)}$. It is known that weakening chronic conditions can represent risk factors for surgical wound infections, due to the host's low resistance level(13).

Most orthopedic surgeries were classified as clean surgeries $(91 \%)$, in line with studies that identified clean orthopedic surgery percentages ranging between $82.3 \%$ and $99 \%(10,20)$. A prospective study of orthopedic surgeries found that the infection risk increases proportionately to the wound contamination degree(8). A Serbian study of orthopedic surgeries found an SSI incidence rate of $13.5 \%$ in patients whose surgery was classified as clean, increasing by $70 \%$ when the surgery was classified as infected ${ }^{(10)}$.

In this study, in turn, no statistically significant association was found between general anesthesia use in patients submitted to orthopedic surgery and SSI, in line with another Brazilian study ${ }^{(8)}$.

It was identified that most surgical procedures were elective, without any association between this variable and the infection. Other authors support this finding, defining that emergency surgeries do not seem to constitute a risk factor for $\mathrm{SSI}^{(8,10)}$. A study about infection shows that SSI incidence levels seem to be higher after emergency surgeries due to the severity of surgical patients, greater difficulty involving the surgical technique and lack of preoperative patient

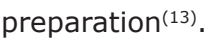

The use of orthopedic implants showed no association with the SSI. This finding differs from a Brazilian study involving orthopedic surgeries ${ }^{(8)}$. The presence of an implant is acknowledged for its ability to enhance an infection and develop immune system resistance to microbial agents. Also, the type of material used to make the prosthesis and its design can determine the bacterial colonization of its surfaces ${ }^{(21)}$.

In this study, the following variables showed no association with SSI: gender $(p=0.07)$, orthopedic implant $(p=0.02)$, general anesthesia $(p=0.00)$, emergency $(R R=1.13 ; 95 \% C I=0.93-1.38 ; p=0.03)$, NNIS Surgical Infection Risk Index $(p=0.18)$, age $(p=0.10)$ and preoperative hospitalization time $(p=0.30)$. The variables length of surgery, preoperative clinical conditions of patient assessed using ASA $>2$, type of surgical procedure OMS $(p=0.04)$ and PROS-Q $(p=0.00)$, surgical wound contamination potential (contaminated and infected surgeries) showed to be associated with SSI. In a study of orthopedic infections, the type of surgical procedure variable showed no statistical association with $\mathrm{SSI}^{(8)}$. Studies have demonstrated disagreement as to the association between these risk factors and SSI development $(4,6,8-10,12)$.

As mentioned, this research identified four SSI risk factors related with SSI development, which nurses should know about in advance with a view to infection monitoring and the establishment of early prevention measures. Nurses should also take into account other risk factors identified in literature for infection prevention in orthopedic surgeries, such as the use of implantation material and the length of preoperative hospitalization.

In turn, it is considered that the identification of SSI risk factors can support the proposal of a new nursing diagnosis for clinical nursing practice in the surgical area, which covers patients' extrinsic and intrinsic vulnerability to infections by pathogenic microorganisms in surgical sites.

\section{Conclusions}

The SSI incidence rate was $1.8 \%$, below the rate considered acceptable and described in literature. This data might indicate under-notification of the event under analysis. The most frequent infections were deep surgical site infection and osteomyelitis.

Surgical wound contamination potential, patient's clinical conditions (ASA), type of surgical procedure and surgery length were variables statistically associated with SSI and behaved as risk factors.

Nurses' knowledge on surgical site infection is fundamental to monitor and put in practice pre, peri and postoperative nursing care for surgical patients and can influence clinical practice, as nursing care should be planned for infection control purposes. It can be affirmed that infection rates associated with care are important patient care quality assessment parameters.

Further research is needed with a view to the identification and validation of the Nursing diagnosis Risk for Surgical Site Infection, which NANDAInternational is analyzing involving patients in other surgical specialties. 


\section{References}

1. Ministério da Saúde. Agência Nacional de Vigilância Sanitária (BR). Segurança do Paciente em Serviços de Saúde: Higienização das Mãos. Brasília (DF): Ministério da Saúde; 2009. 105p. [acesso 13 out 2010]. Disponível em: http://www.anvisa.gov.br/servicossaude/manuais.

2. Pina $E$, Ferreira $E$, Marques A, Matos B. Infecções associadas aos cuidados de saúde e segurança do doente. Rev Port Saúde Pública. 2010;(10):27-39.

3. Rodarte RRP, Leite JPB. Avaliação do perfil epidemiológico dos pacientes portadores de infecção pós artroplastia total de joelho. Rev Into Rio de Janeiro. $2006 ; 4(1): 23-40$.

4. Oliveira AC, Braz NJ, Ribeiro MM. Incidência da infecção do sítio cirúrgico em um hospital universitário. Cienc Cuidado Saúde. 2007;6(4):486-93.

5. Center for Disease Control and Prevention (USA). The National Healthcare Safety Network (NHSN). Manual Pacient Safety Component Protocol Division of Healthcare Quality Promotion National Center for Preparedness, Detection and Control of Infectious Diseases. Atlanta, GA (USA). 1-1 a 17-32 p. [acesso 12 jun 2011]. Disponível em: http://www. cdc.gov//nhsn/ TOCPSCManual.html.

6. Khan MS, Rehman S, Ali MA, Sultan B, Sultan S. Infection in Orthopedic Implant Surgery, Its Risk Factors and Outcome. J Ayub Med Coll Abbottabad. 2008;20(1):23-5.

7. Ministério da Saúde. Agência Nacional de Vigilância Sanitária (BR). Sítio Cirúrgico. Critérios de Infecções relacionadas à assistência à saúde. Brasília (DF): Ministério da Saúde; 2009. 19 p. [acesso 12 out 2010]. Disponível em: http://www.anvisa.gov.br.

8. Ercole FF, Chianca TCM, Duarte D, Starling CEF, Carneiro M. Surgical Site Infection in Patients Submitted to Orthopedic Surgery: The NNIS Risk Index and Risk Prediction. Rev. Latino-Am. Enfermagem. 2011;19(2):269-76.

9. Lima ALM, Zumiotti AV, Uip DE, Silva SJ. Fatores preditivos de infecção em pacientes com fraturas expostas nos membros inferiores. Acta Ortop Bras. 2004;12(1):23-39.

10. Maksimovic' J, Markovic'-Denic' L, Bumbasirevic' M, Markovic J, Viajinac H. Surgical site infections in orthopedic patients: prospective cohort study. Croat Med J. 2008;49(1):58-65.
11. Anderson DJ, Kaye KS, Classen D, Arias KM, Podgorny K, Burstin $\mathrm{H}$, et al. Strategies to Prevent Surgical Site Infections in Acute Care Hospitals. Infect Control Hosp Epidemiol. 2008;29:s51-s61.

12. Ercole FF, Chianca TCM. Infecção de sítio cirúrgico em pacientes submetidos à artroplastia de quadril. Rev. Latino-Am. Enfermagem. 2002;10(2):157-65.

13. Mangran $\mathrm{AJ}$, Horan $\mathrm{TC}$, Pearson $\mathrm{ML}$, Silver $\mathrm{CL}$, Jarvis WR, Jarvis WR. Guideline for prevention of surgical site infection. Infect Control Hosp Epidemiol. 1999;20(4):97-134.

14. Nanda Internacional. Diagnósticos de Enfermagem da NANDA: definições e classificações 2009-2011. Porto Alegre: Artmed; 2009. 453 p.

15. New Classification of Physical Status. Anesthesiology. $1963 ; 24: 111$.

16. Hosmer JR, David W, Lemershow S. Applied Logistic Regression. New York: John Wiley; 1989. 307p.

17. Oliveira AC, Carvalho DV. Evaluation of underreported surgical site infection evidenced by postdischarge surveillance. Rev. Latino-Am. Enfermagem. 2007;15(5):992-7.

18. Martins MA, França E, Matos JC, Goulart EMA. Vigilância pós-alta das infecções de sitio cirúrgico em crianças e adolescentes em um hospital universitário de BH MG Brasil. Rev Saúde Pública. 2008;24(5):1033-41. 19. Nichols RL. Preventing Surgical Site Infections. Clin Med Res. 2004;2(2):115-8.

20. Ridgeway S, Wilson J, Charlet A, Kafatos G, Pearson $A$, Coello R. Infection of the surgical site after arthroplasty of the hip. J Bone Joint Surg. 2005;87-B:844-50.

21. Miclau T, Schmidt AH, Wenke JC, Webb LX, Harro JM, Prabhakara $R$, et al. Infection. J Orthop Trauma. 2010;24(9):583-6.
Received: Mar. $4^{\text {th }} 2011$ Accepted: Sept. 29th 2011 